\title{
Animals in Islamic Tradition and Muslim Cultures
}

\author{
Richard M. Foltz
}

Oxford: One World, 2006. 192 pages.

In his peculiarly self-abasing preface to Animals in Islamic Tradition and Muslim Cultures, Richard Foltz speculates that the audience for his book will probably consist of "non-Muslims who are sympathetic to Muslim culture and interested in learning more about what it has to offer in terms of animal rights" (p. xii). This appears to be less of a prediction than a presupposition guiding the book. Appropriately, Animals in Islamic Tradition is a very broad outline of representations of non-human animals from the preIslamic era to the present in as many fields as a 192-page book can encompass. As a result, his study tends to be kaleidoscopic, treating each subject in a very general manner, hastily running through the basics and garnishing them with selected curiosities. For perhaps the same reason, the book is written in a very simple style, neither extremely engaging nor boringly obscure, and tends to provide summary rather than analysis.

The issue of the non-human animal in Islam and in Islamicate cultures is not a single question, but rather a vast number of disparate questions that ultimately require detailed attention in themselves. Given the lack of attention hitherto received by each of these specific questions, any general survey such as Foltz's must necessarily be tentative and exploratory. The book is divided into seven chapters that deal, respectively, with references to animals in the Qur'an and the hadith literature (chapter 1), animal-related injunctions in Islamic law (chapter 2), scientific and philosophical studies (chapter 3), literary and artistic representations (chapter 4), animal rights in the contemporary era (chapter 5), Islamic vegetarianism (chapter 6), and Muslim attitudes toward dogs (chapter 7). Each chapter is further divided into several subheadings, making the book something of a collection of wellcategorized articles rather than a tightly bound narrative building up to a central argument. 
That being the case, Animals in Islamic Tradition does seem to have, if not a thesis, then at least a slant: it is clearly concerned with championing animal rights and identifying the sources from which an Islamic emphasis on animal rights, an Islamic vegetarianism, and the like might justify themselves. Foltz claims that his book is not meant to be one-sided, and he certainly recounts Muslim justifications for meat-eating and negative attitudes toward certain animals. However, particular weight is given to Muslim proponents of animal rights and vegetarianism and to those individuals who are set up as their predecessors. People such as the vegetarian poet al-Ma`arri, the British imam and animal rights advocate Basheer Ahmad Masri, and Egyptian dog-lover Ahmed Tharwat are undoubtedly the heroes of this book.

Foltz's chapter on Islamic law, as well as his fifth and sixth chapters, outline the aids and impediments to furthering animal rights in the Islamicate world and trace the progress made thus far. The story that the book tells appears designed to unearth the successes of Muslim conservationists and animal lovers and to provide present and future Muslim animal rights activists with a history to inspire and guide their efforts. Particularly important to this narrative are the various fatwas issued by religious scholars with regard to human-animal relations. Foltz argues that in the Shari ah "[i]t is assumed without question that humans are going to make use of animals and to eat them; the legal questions therefore center on how to define and circumscribe the limits of these behaviors" (p. 30).

Nevertheless, the selected legal opinions show that there is a fairly considerable body of injunctions regarding the treatment of domesticated animals. For example, the lists of rules given by the thirteenth-century Shafi $i$ jurist 'Izz al-Din al-Sulami and by the modern Shi ite jurist Hashem Najy Jazayery, both of whom look unfavorably upon punishing animals and forcing them to carry excessively heavy loads are presented (pp. 34-35). In addition, the author refers to examples of wildlife preserves and their status according to Islamic law (pp. 36-41). He concludes that Islamic law requires a new era of ijtihad (independent judgment on a legal or theological question) if it is to become more just toward animals in keeping with the new realities of the twenty-first century, such as factory farming and extinction.

The chapters on the representation of animals in philosophical, scientific, and literary texts and art, present the reader with an overview of various mainly pre-twentieth-century sources, including Sufi literature, bestiaries, and fables. Animals in Islamic Tradition is overwhelmingly concerned with the practical issues that are of interest to environmentalists and animal rights activists, and thus does not dwell at any length on the finer the- 
oretical questions, such as the question of what constitutes humanness as opposed to non-human animality. Many of the sources presented in these chapters, and particularly the philosophical texts with their Aristotelian and Neoplatonic inheritances, might have been presented in the context of an exploration of this question of humanity versus animality.

Although the book stresses the importance of the Arabic translation of Aristotle's properly zoological works (Historia Animalum is mentioned) and notes his importance to Islamicate philosophy, it appears to avoid any investigation into the more abstract discussions of animality in the Arabic version of De Anima, commented on by Ibn Sina and Ibn Rushd. It also does not look into possible Muslim responses to references made about the animal in the important Neoplatonic source text Theologia, an Arabic translation of a work wrongly attributed to the Greek philosopher Plotinus. Instead, al-Razi's qualms about hunting are alluded to alongside environmental and taxonomical ideas in the Ikhwan al-Safa's fascinating Case of the Animals versus Man before the King of the Jinn (Fi Tada `i al-Hayawanat 'ala al-Insan 'inda Malik al-Jinn) and the bestiaries of al-Jahiz and al-Damiri.

For those who wish to learn about animal rights and Islam, but who are beginners when it comes to either or both, this will be an interesting book and an easy read. As for those who wish to delve deeply into a particular aspect of this issue, Foltz's bibliography is a useful - though by no means comprehensive - pointer to the source texts to which they should turn. 